\title{
How MANY 'Clicks' DOES IT TAKE? FINDING PRICE INFORMATION ON NEW ZEALAND LAWYERS' WEBSITES
}

\author{
Louisa Choe
}

\begin{abstract}
This article examines price transparency in New Zealand's civil legal services market and compares the civil legal services market characteristics to those of other jurisdictions. The current law does not incentivise providers within the legal services market to communicate price information to consumers searching for a provider. The researcher utilised a web-sweep method to assess how New Zealand law firms that provide dispute resolution services and employment advocates share information through their websites. The web-sweep covered the websites of $96 \mathrm{New}$ Zealand law firms and $30 \mathrm{New}$ Zealand employment advocates. The author assessed the ease with which prospective consumers could navigate and understand price-related information. The results demonstrated that in a majority of instances, price information is unclear and uncertain. It is therefore not comparable between providers. Consumers in New Zealand face a high search cost when looking for prices and deciding on a legal service provider. They are unable to make a meaningful price comparison between providers of dispute resolution services before engaging them. Stronger regulation of providers (lawyers and employment advocates) to require the display of pricing information would lower search costs for consumers and increase competition.
\end{abstract}

\section{INTRODUCTION: THE IMPORTANCE OF PRICE TRANSPARENCY}

In New Zealand, like many jurisdictions, legal services are expensive. Civil dispute resolution services are no exception, and uncertainty about the length and dynamics of a dispute creates

* Louisa Choe is a postdoctoral research fellow with the Building New Zealand's Innovation Capacity team (BNZIC) within the Science of Technological Innovation National Science Challenge and is currently based at the University of Otago. He pūkenga rangahau kairangi a Louisa Choe kei te rōpū Building New Zealand's Innovation Capacity (BNZIC) i roto te Science of Technological Innovation National Science Challenge, ā, e mahi ana i tēnei wā i te Whare Wānanga o Ōtāgo. Email/Īmēra: louisa.choe@otago.ac.nz. 
particular problems with estimating the total price. ${ }^{1}$ Access to legal advice in a dispute is vital as the advice can be crucial to enforcing or defending legal rights. How can the price of dispute resolution services be reduced to make them more accessible? There is an array of possibilities. ${ }^{2}$ One of these possibilities is to increase the availability of price information for clients searching for a lawyer. This article examines the price information made available by lawyers on their websites and whether this could be improved to lower search costs and increase competition, thus improving access to justice.

The availability of upfront price information to consumers is an essential feature of a competitive and well-functioning market. ${ }^{3}$ This means that consumers have access to price information and can review and compare those costs between providers, intensifying competition between service providers. ${ }^{4}$ When prices are transparent, consumers can also understand how fees are calculated, ${ }^{5}$ for example, in the case of legal services, how hourly billing operates.

Research in the United Kingdom (UK) indicated price information scarcity within the UK legal services market. ${ }^{6}$ In New Zealand, there is little research on price information in the context of dispute resolution legal services. However, in the context of a review of switching costs in professional services, the Ministry of Business, Innovation, and Employment commented that legal service providers display little information on the price of their services. ${ }^{7}$ This lack of price information means that few consumers have a clear idea of the costs involved in dispute resolution. Evidence of

1 See Chief Justice Helen Winkelmann "Access to Justice - Who Needs Lawyers?" (2014) 13(2) Otago Law Review 229; and Frances Joychild QC "Continuing the Conversation ... the Fading Star of the Rule of Law" (5 February 2015) 1 Law News (Auckland District Law Society) 3.

2 Bridgette Toy-Cronin "Explaining and changing the price of litigation services" (2019) 9 NZLJ 310 at 312.

3 Peter Møllgaard and Per Baltzer Overgaard Market Transparency and Competition Policy (Copenhagen Business School, 2001) at 2.

4 At 3. See also Christopher Whaley "Provider Responses to Online Price Transparency" (2019) 66 J Health Econ 241 at 252; and Nelson Granados, Alok Gupta and Robert Kauffman "Designing Online Selling Mechanisms: Transparency Levels and Prices" (2008) 45 Decision Support Systems 729 at 731.

5 D Andrew Austin and Jane Gravelle Does Price Transparency Improve Market Efficiency? Implications of Empirical Evidence in Other Markets for the Health Sector (The United States Congressional Research Service Report, July 2007) at 5.

6 Competition and Markets Authority Legal services market study (Government of the United Kingdom, 2016) at 73 .

7 Ministry of Business, Innovation and Employment Search and Switching Costs in the Services Sector: Literature Review (New Zealand Government, 2017) at 7. 
this market failure is that many in person litigants in New Zealand, those who choose to represent themselves in court, initially retain a lawyer but subsequently run out of funds. ${ }^{8}$

The first part of this article outlines the nature of legal services (focusing on dispute resolution services) in New Zealand and the regulatory setting. This section explains why price transparency can lower prices and surveys the current discussion about search cost, information scarcity, and competition. In the second Part, I present the results of a web-sweep of 96 litigation firms and 30 nonlawyer employment advocate firms. In New Zealand, assistance in employment matters is not reserved to lawyers, nor does it need to be. ${ }^{9}$ The inclusion of employment advocate firms was due to this body of service providers offering advocacy services in employment disputes while remaining unregulated. This study questions whether this unregulated sector offers a higher degree of price transparency to those offered by lawyers.

The employment advocate sector has no regulatory framework that currently exists to address any issues of competence. Nor does a complaints mechanism exist. ${ }^{10}$ Yet, employment advocates can represent consumers in the early stages of resolution and at mediation. Having a variety of legal service providers should create price competition and drive prices down. The existence of an alternative sector, the employment advocates, arguably encourages access to justice, affording representation to otherwise disenfranchised individuals. ${ }^{11}$ The web-sweep examined the pricing information given to consumers searching for a provider via the firms' websites and how improving the quality of this information could assist clients looking for advice with a legal dispute.

\section{A Providers and Pricing of Dispute Resolution Services in New Zealand}

In New Zealand, lawyers have an exclusive right to offer services within the "reserved area of work", as defined in s 6 of the Lawyers and Conveyancers Act 2006 (LCA). ${ }^{12}$ The area is defined as the "direction or management" of proceedings before a court and appearing in court. Most lawyers providing litigation services use hourly billing. ${ }^{13}$ Although hourly billing is a common form of pricing strategy, there is limited information on New Zealand lawyers' charge-out rates. The Niche Consulting Group Legal Salary Survey (2018) found that the average charge-out rates for lawyers employed with

8 Melissa Smith, Esther Banbury and Su-Wuen Ong Self-Represented Litigants: An Exploratory Study of Litigants in Person in the New Zealand Criminal Summary and Family Jurisdictions (research report prepared for the Ministry of Justice, July 2009) at 44.

9 Employment Relations Act 2000, s 236.

10 Ward v Concrete Structures (NZ) Ltd [2019] NZEmpC 111 at [10]-[12].

11 Sarah Dippie Non-Lawyer Employment Advocates and the Trade-Off Between Accessibility and Capability (LLB (Hons) Dissertation, University of Otago, 2020) at 27.

12 Lawyers and Conveyancers Act 2006 (LCA), s 6.

13 Bridgette Toy-Cronin and others New Business Models for Legal Services (Working Group on Access to Justice, discussion paper prepared for the New Zealand Bar Association, 2016) at 2. 
more than two years of post-qualification experience sat between $\$ 250$ to $\$ 350$ per hour. ${ }^{14}$ The range which computed this average was broad (spanning from $\$ 23$ per hour to $\$ 680$ per hour). The chargeout rate for lawyers in large firms was, on average, higher than that for medium and small firms. Several contributing factors impact what lawyers charge, but the firm's partnership typically sets these rates. Individual lawyer rates are dependent on location, years of experience, potential target profit set by the partnership, and gender. ${ }^{15}$ This variability in what lawyers are charging means that the average charge-out rates information is of limited assistance for litigants budgeting for their legal services.

There is little incentive for providers to communicate price information. New Zealand's legal services market adopts what is recognised as a "co-regulatory" approach. ${ }^{16}$ Theoretically, this approach provides more room for competition promotion than - the cynic might suggest - a selfregulatory system would. However, the distinctions between self-regulation, co-regulation, and government regulation are, at times, blurred, and in practice, the New Zealand Law Society possesses considerable influence. ${ }^{17}$ There are no specific rules regulating price transparency within the legal services market in New Zealand. The only rules relating to pricing are about the total price charged, as set out in the Lawyers and Conveyancers Act (Lawyers: Conduct and Client Care) Rules 2006 (the Rules). The Rules set out the factors that must be taken into account when determining a fair and reasonable price and include: the skill, specialised knowledge, and responsibility required; the importance of the matter to the client and the results achieved; the urgency and circumstances in which the business is transacted; the complexity of the matter; the difficulty or novelty of the questions involved; and the time and labour expended. ${ }^{18}$ While the LCA and the Rules govern lawyers' fees, they lack specificity. They do not explicitly set limits on how much lawyers can charge and do not regulate the quality and standard of price information that must be made available. Neither do the LCA and the Rules set definitions on what is considered anti-competitive behaviour.

However, lawyers are not the only providers in the dispute resolution market; there are several exceptions made under the statute that allows non-lawyers to offer services. ${ }^{19}$ An example is an exception made for non-lawyers to represent clients facing employment-related disputes. Often referred to as "employment advocates" (although they also take names such as "employment law

14 New Zealand Law Society and Niche Consulting Group Legal Salary Survey 2018 (New Zealand Law Society, 2018) at 26.

15 Allie Cunninghame and Bridgette Toy-Cronin Assessing Legal Services: The Price of Litigation Services (University of Otago Legal Issues Centre, 2019) at 12.

16 Selene Mize "New Zealand: Finding the Balance between Self-Regulation and Government Oversight" in Andrew Boon (ed) International Perspectives on the Regulation of Lawyers and Legal Services (Hart Publishing, London, 2017) 115 at 123.

17 At 124

18 Rule 9.

19 LCA, s 27. 
experts" or "employment law specialists"), they are entirely unregulated. There is no practising licence for employment advocates, and there is no regulatory body overseeing the practice. ${ }^{20}$ While employment advocates have a professional body - the Employment Law Institute of New Zealand (ELINZ) - membership of this professional body is voluntary and it has no power or legal standing. ${ }^{21}$ The lack of regulation of employment advocates means there are no requirements for price information to be provided to consumers.

While there is no requirement to display pricing information for either lawyers or non-lawyers, the competition in the employment dispute space should theoretically lower prices. Evidence shows that the emergence of new entries within the legal services market can stimulate competition within the sector. The overall "real fee" for that good or service is likely to be reduced. ${ }^{22}$ At the same time, the information provided to clients should improve. ${ }^{23}$ The lack of employment advocates' regulation should also enable employment advocates to offer consumers more competitive services and lower prices. ${ }^{24}$ Indeed, Shulruf and colleagues' study demonstrated that the cost for resolving employment disputes where advocates for employees were involved was lower (the mean price of $\$ 7,681$ ) than a dispute involving lawyers (mean price of $\$ 18,359$ ). ${ }^{25}$ However, it is not clear whether the presence of employment advocates in the market is lowering the price of lawyer-provided employment services.

\section{B Legal Services as Goods}

There are two broad aspects to price information in dispute resolution services: the rates and charging methods (for example, hourly rate and time-based method, compared to what the total cost). Providing information on rates and charging methods presents no particular complexity, but it is much more challenging to provide information about the total cost due to the difficulty of assessing the time required on a case at the start. The dominant use of hourly billing contributes to total price uncertainty. Such a pricing method restricts consumers' ability to compare the total price.

20 The Employment Law Institute of New Zealand [ELINZ] is a membership organisation for "employment law professionals" established to "promote and enhance professional standards of employment law advocacy". The ELINZ (2020) <www.elinz.org.nz>.

21 One of ELINZ's four objectives is to "support and advocate for statutory regulation of lay employment advocacy services in New Zealand". See ELINZ, above n 20.

22 Boaz Shulruf and others "Grievance Gravy Train Picking up Speed: Myths and Reality around Employment Disputes in New Zealand" (2019) 51 J Ind Relat 245 at 252.

23 Simon Domberger and Avrom Sherr "The Impact of Competition on Pricing and Quality of Legal Services" (1989) 9 Int Rev Law Econ 41 at 55.

24 Competition and Markets Authority Regulation and Competition (Government of the United Kingdom, 2020) at 22 .

25 Shulruf and others, above n 22, at 252. 
Price information is only one aspect of the information the consumer may find difficult to access. International literature has shown that consumers often face additional deficits in their knowledge when seeking help in a legal dispute: awareness of the legal services sector, including whether issues are 'legal' and the different types of providers available to consumers. ${ }^{26}$ They will also face difficulties judging the quality of the services on offer. These issues stem in large part from the fact that legal services exhibit characteristics of credence goods. ${ }^{27}$ These are goods where the provider of the service possesses more information than the consumer of the service. ${ }^{28}$ The consumer cannot foresee and understand what kind of legal remedy is suitable for their needs before the lawyer's diagnosis. ${ }^{29}$ Arguably, this is true both before and after the service has been provided; the provider can typically ascertain the kind or quality of service the consumer needs, but the consumer cannot usually verify the need for the service or the service's quality they have received.$^{30}$ For a consumer to judge the quality of a lawyer's service, they would need to seek the advice of another lawyer, but as Hadfield explained, even this might not give them the answers: ${ }^{31}$

Law is not merely complex. It is so complex that it is also highly ambiguous and unpredictable. The necessity and quality of legal services are not merely difficult for nonexperts to judge; they are also difficult for experts, even the expert providing the service, to judge. This magnifies the credence problem dramatically.

The credence problem creates a significant difficulty in understanding what services the consumer requires, how much of the service they need, and the service's quality. It is therefore challenging for consumers to estimate the total cost for the legal services they require. The legal services market joins the healthcare industry as one of the few markets where consumers risk making significant purchase decisions without knowing how much they must pay. ${ }^{32}$

The credence characteristics of legal services' have led some commentators to believe that a lack of market competition is inevitable. For example, Andrew Boon described the ambition of legal

26 Competition and Markets Authority, above n 6, at 8 .

27 Gillian Hadfield "The Price of Law: How the Market for Lawyers Distorts the Justice System" (2000) 98 Mich Law Rev at 968.

28 Loukas Balafoutas and Rudolf Kerschbamer "Credence goods in the literature: What the past fifteen years have taught us about fraud, incentives, and the role of institutions" (2020) 26 J Behav Exp Finance 1 at 2.

29 Kees Hellingman "An Economic Analysis of the Regulation of Lawyers in the Netherlands" in Michael Faure and others (eds) Regulation of Professions (Maklu Uitgevers, Antwerp, 1993) 172 at 174.

30 Balafoutas and Kerschebamer, above n 28, at 2. See also Alessandra Caron "The legal profession between regulation and competition" (LLM thesis, Erasmus University, 2008) at 16.

31 Hadfield, above n 27, at 969.

32 Yoshimi Anzai, Kathy Delis and Robert C Pendleton "Price Transparency in Radiology - A model for the Future" (2020) 17 JACR 194 at 198. 
services regulators in England and Wales to make the market more competitive as a "golden dream". ${ }^{33}$ Addressing price information scarcity can be a thorny challenge for regulators, as filling the price information vacuum requires regulators and law firms to work with the complexity of time-based billing. ${ }^{34}$ Alternative pricing models can also be challenged by the same credence characteristic of legal services, given the uncertainty of what service may be required at the start. However, optimists within the industry have argued that legal services regulations could "try to take the bull by horns" and break down the impediments to competition within the legal services market. ${ }^{35}$ One way this can be done is to lower search costs by increasing disclosure requirements by law firms. ${ }^{36}$ For example, the Competition and Markets Authority in the United Kingdom proposed that regulators: ${ }^{37}$

should revise their regulatory requirements to set a new minimum standard for disclosures on price and the service provided and develop and disseminate best practice guidance. Importantly, this should include a requirement for providers to publish relevant information about the prices consumers are likely to pay for legal services.

Other strategies to lower search costs by improving price information include regulators building an online directory of law firms where prices can be compared, essentially creating what the Canadian Bar Association's Legal Futures Initiative report terms an "electronic marketplace". ${ }^{38}$ However, there may be limitations to an "electronic marketplace" solution due to the complexity of legal service requirements and how they vary from case to case. Another strategy is for organisations to survey and publicise information about the price of legal services, making price information available for consumers. ${ }^{39}$

Given the complexity of legal services, it is no simple matter to increase competition between providers and assist with lowering prices. Increasing the availability of pricing information will,

33 Andrew Boon (ed) "England and Wales: Cocktails of Logics-Reform of Legal Services Regulation in England and Wales" in International Perspectives on the Regulation of Lawyers and Legal Services (Bloomsbury Publishing, London) at 203.

34 Noel Semple "Mystery shopping: demand-side phenomena in markets for personal plight legal services" (2019) 26 Int J Legal Prof 181 at 200.

35 At 201 .

36 At 201

37 Competition and Markets Authority, above n 6, at 15

38 Canadian Bar Association CBA Legal Future Initiative - The Future of Legal Services in Canada: Trends and Issues (Canadian Bar Association, 2013) at 21.

39 Organisation for Economic Co-operation and Development Policy Roundtables: Competition in Professional Services 1999 (OECD, 1999) at 152. 
however, go some way to increasing competition, as well as helping consumers protect their own interests. ${ }^{40}$

However, it should be noted that some economists caution that in the wrong market conditions, price transparency could act as a facilitator to anti-competitive behaviours (for example, colluding to behave like an oligopoly) because it facilitates sharing price information between providers. ${ }^{41}$ This concern has limited force in the legal services market. The complexity of legal disputes means that only the provider with detailed information about a particular case will know enough detail to estimate the total price. This asymmetry of information between firms reduces the likelihood of the postulated anti-competitive behaviour. ${ }^{42}$ As such, the expectation of price transparency among legal service providers is limited to their hourly rate.

Notably, price information on legal service providers' hourly rates and how these rates apply will lower barriers for consumers searching for a provider. ${ }^{43}$ Searching for legal services has a high temporal cost; it takes time for consumers to identify and compare alternatives in selecting a legal service provider. ${ }^{44}$ If price information is not readily available, this temporal cost increases, and rational consumers will only seek information when the trade-offs between perceived benefits exceed the cost of doing so. ${ }^{45}$ In the UK legal services market, where there is price information scarcity, few consumers of legal services can compare price information before making an informed decision. ${ }^{46}$ This likely explains why only 27 per cent of personal dispute litigants reported shopping around before choosing a law firm. ${ }^{47}$

For many would-be clients seeking price information, the internet will be their first point of search. However, overseas evidence shows that there is limited price information available online. For example, in England and Wales, only six per cent of consumers could find price information on law

40 Semple, above n 34, at 184 .

41 Gary Hewitt "Price Transparency: Will a Greater Degree of Price Transparency Help or Harm Buyers?" (2003) 5 OECD J Comp Law Pol 109 at 120.

42 Semple, above n 34, at 195.

43 Competition and Markets Authority, above n 6, at 94; and Ministry of Business, Innovation and Employment, above $\mathrm{n} 7$, at 11 .

44 Semple, above n 34, at 184.

45 Simon Anderson and Regis Renault "Firm pricing with consumer search" in Luis Corchon and Macro Marini (eds) Handbook of Game Theory and Industrial Organization (Edward Elgar Publishing, Cheltenham, 2017) 1 at 20.

46 Competition and Markets Authority, above n 6, at 94.

47 Legal Services Consumer Panel (England and Wales) Tracker Survey 2017 Briefing Note: how consumers are choosing legal services (2017) at 2. 
firms' websites. ${ }^{48}$ For prospective consumers who cannot attain price information on the legal service providers' hourly rates online, they must telephone the firm or acquire the information at the first meeting with the lawyer, both of which are likely to entail the client repeatedly telling their story. ${ }^{49}$ Given that events giving rise to civil legal disputes are often traumatic, stressful, and likely to be unpleasant, urgency is often a characteristic demanded from such legal needs. ${ }^{50}$ High search costs, therefore, impede comparison shopping. ${ }^{51}$ For consumers to compare prices, price information on service providers' hourly rates and how these rates apply needs to be clear and certain. ${ }^{52}$

This article seeks to investigate how readily New Zealand law firms communicate price information through their websites and how this compares to employment advocates' price information. The purpose is to assess whether the price information provided by law firms and employment advocates could be improved to help create more a more competitive and efficient market.

\section{METHOD}

This article uses data gathered through a web-sweep to explore the availability of price information (rates and charging methods) within the New Zealand legal services market. I adopted a prospective consumer's role, as this market participant perspective can illustrate the navigation process required to attain price information. The consumer envisaged is an individual facing a litigious matter who has some means to pay (for example, not a legal aid client or a client searching for pro bono assistance) and is conducting an initial search for dispute resolution services. This envisaged consumer can either be instigating or defending litigation. I collected two samples: law firms and employment advocates.

For the law firm sample, 96 websites were selected from a list of law firms involved in High Court litigation generated in a previous study. ${ }^{53}$ These firms range from large firms primarily but not exclusively targeting corporate clients to smaller firms whose client base will include more individuals. The selected firms were geographically dispersed. The relevant price information

48 At 2 .

49 Australian Government Productivity Commission Access to Justice Arrangements (Government of Australia, 2014) at 190.

50 Semple, above n 34, at 189.

51 Competition and Markets Authority, above n 6, at 271.

52 Legal Services Consumer Panel (England and Wales) Opening up data in legal services (2016) at 12.

53 See Bridgette Toy-Cronin and others The Wheels of Justice: Understanding the Pace of Civil High Court Cases (University of Otago Legal Issues Centre, 2017) at 16. 
published by each firm was collated using NVivo and NVivo Capture. ${ }^{54}$ For the sample of employment advocates, a total of 30 websites were selected using the Google search function and the keywords "NZ employment advocate". I used a web browser in private browsing mode (as it allowed the search browser to dictate the order of the results), and the first 30 websites were selected as part of the sample. I collected both samples in September and October 2020.

I examined both samples to assess what information each firm provided on their website, including specific rates, price models, other applicable fees, and, if available, how this information was communicated. I looked for similarities and differences between the two samples.

Since this study concerns consumers' search cost when deciding whether to pursue a legal matter and to engage the relevant legal or dispute service, I adopted grounded theory when collecting, coding, and analysing the data. Grounded theory is an inductive, comparative, iterative and interactive method of collecting and analysing data. ${ }^{55} \mathrm{I}$ used grounded theory because it complemented the explorative nature of this study, where I inhabited a prospective litigant's gaze in search of price information. Additionally, grounded theory allowed the study to emphasise the phenomenon or process rather than a description of the (web) setting. ${ }^{56}$ Thus, when analysing the web-sweep data, I made "replicable and valid inferences from texts (or meaningful matter)" 57 in the context of the availability of price information. The use of an autoethnographic technique also allowed me to record my navigation of the websites and price information as "scientific prose". 58

Additionally, to understand how easy or difficult it is to understand price-related information on law firms' websites, I calculated each website's Flesch-Kincaid readability score test. Then, I entered a paragraph on the website's price information into an online readability calculator. ${ }^{59}$ The FleschKincaid grade level readability score indicates the number of years of education generally required to understand the text, where a higher score indicates a higher degree of difficulty. ${ }^{60}$ Finally, to better

54 NVivo is a qualitative and mixed method data organizational tool. NVivo Capture is an extension tool that enables the capturing of data from an internet search browser, and to convert this data into a Portable Document Format [PDF], that can be uploaded into NVivo.

55 Kathy Charmaz Constructing Grounded Theory: A Practical Guide through Qualitative Analysis (2nd ed, Sage, Thousand Oaks, 2014) at 22.

56 At 22 .

57 Klauss Krippendorff Content Analysis: An Introduction to Its Methodology (Sage, Thousand Oaks, 2004) at 18.

58 Sally Jo Cunningham and Matt Jones "Autoethnography: a tool for practice and education" (paper presented to the Association for Computing Machinery Conference, New York, 2005) 1 at 2.

59 WebFX "Readability Test Tool" (2020) <www.webfx.com>.

60 On the formula for the Flesch-Kincaid Readability score, see J Peter Kincaid and others Derivation of new readability formulates (Automated Readability Index, Fog Count and Flesch Reading Ease Formula for Navy enlisted personnel) (Institute for Simulation and Training, 1975). 
understand the complexity of navigating price information through law firms' websites, I conducted a comparative analysis between the price information from the sample of law firms' websites and employment advocates' websites. This comparison offered an insight into how similar or different the two sectors are in communicating price information.

\section{RESULTS OF LAW FIRM WEB-SWEEP}

Law firms' websites were divided into three categories of transparency based upon the extent of price information they had made available. Category A was the most transparent, firms that provided prices in the form of hourly rates (4.2 per cent, $n=4)$. Category B firms did not provide pricing but stated how their fees were calculated $(46.9$ per cent, $n=45)$. These firms' websites usually explained the factors that might affect pricing. Most firms were in Category C ( 48.9 per cent, $n=47$ ), where the website had no information on price.

Among the firms that published price information on their websites (those belonging to Category A and B (51.1 per cent, $n=49)$, almost all ( 87.8 per cent, $n=43$ ) provided price information in their Terms of Engagement online. The Terms of Engagement documents ranged from five to seven pages long. The remaining six firms had a page on their website dedicated to price information.

All four firms' websites in Category A provided the hourly rate information in their Terms of Engagement. These firms' websites broke down the lawyers' hourly rates and the legal executives' rates. For example, one Category A firm published different rates depending on the seniority of the lawyer within the firm: ${ }^{61}$

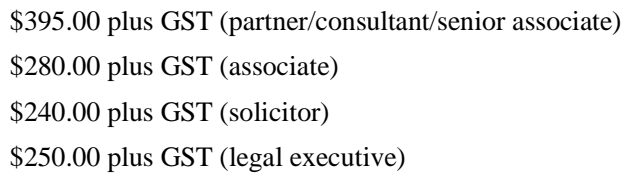

Although all four firms' websites provided price information on their lawyers' hourly rates, the firms' websites did not explain how time-based billing operated (ie, the model used by lawyers to calculate the time spent on a dispute).

Information about time-based billing was, however, present in Category B websites. All Category B websites stated they used time-based billing, and almost one in three firms' websites in this category (31.1 per cent, 14 of 45 ) provided information on how hourly billing operates. For example:62

61 Website 90 .

62 Website 54. 
Where our fees are calculated on an hourly basis, the hourly rates are set out in our engagement letter. The differences in those rates reflect the experience and specialisation of our professional staff. Time spent is recorded in 6-minute units, with time rounded up to the next unit of 6 minutes.

Firms' websites that did not explain how hourly billing was calculated provided descriptions of how hourly billing operated. For example: ${ }^{63}$

... fees are calculated on an hourly basis, the hourly rates of the people we expect to undertake the work are set out in our engagement letter. Any differences in those rates reflect the different levels of experience and specialisation of our professional staff. Hourly fees may be adjusted (upwards or downwards) to ensure the fee is fair and reasonable to take into account matters such as the complexity, urgency, value and importance of the Services.

In summary, for the firms' websites that did not explain how hourly billing was calculated, the applicable hourly rate is dependent on the legal service provider's seniority and specialisation. Although Category B's websites did not include specific price information, they usually referred to the LCA or Rules (80 per cent, 36 of 45) and explained how fees are structured or determined. This example, paraphrasing the LCA, was typical: ${ }^{64}$

Our fees will be charged in accordance with the guidelines set out in the Lawyers: Conduct and Client Care Rules. Our fees will be charged on the basis they are fair and reasonable having regard to the circumstances and the nature of our work for you.

In fixing the fee, we will have regard to the time and other resources involved in carrying out your instructions, the results achieved, the urgency of the matter, the level of skill required to carry out your instructions, the complexity of the matter and the specialist knowledge involved.

Other websites quoted the LCA directly when explaining how they charged their fees; some even mirrored the language of Rule 9, setting out all the factors that a lawyer must take into account when calculating the total price (for example, Website 1).

The majority of law firms' websites reviewed ( 48.9 per cent, $n=47$ ) fell into Category $C$ and were firms that did not include any information or guidance on price. A common characteristic of these websites was the emphasis given to lawyers' profiles or the description of the firms' expertise. In addition, the websites belonged to a diverse range of firms, such as the firms' geographical locations and the number of lawyers advertised on their websites.

63 Website 69.

64 Website 14. 
The findings demonstrated that there is limited price transparency on law firms' websites. The available information leaves the prospective consumer with insufficient information to undertake meaningful price comparisons.

\section{A Ease of Navigating and Understanding Price Information}

The next question to consider is, where the firm did have pricing information (Category A or B, $\mathrm{n}=49$ ), how easy or difficult was it to find this information and understand it? This section considers both these issues.

When assessing how easy or difficult it was to find price information, I identified three degrees of complexity. First, the least complex was where price information or signposting about the price was visible on the website's main landing page (30.6 per cent, $n=15$ ).

The second degree of complexity was where navigation required clicking through tabs or links (53.1 per cent, $\mathrm{n}=26$ ). While some websites (for example, Website 25) required the user to scroll to the bottom to navigate the "Terms of Engagement" link, other websites (for example, Website 51) required their consumers to take a few more steps before locating the relevant price information. The following excerpt details the steps I had to take to navigate the price information on Website 51:

I scrolled through the website's main landing page in search of a signpost that led to the firm's price information. However, the main landing page consisted of the firm's lawyers' profiles and blog posts, along with a "Get in touch" form at the bottom of the page. I then scrolled back up to the top of the landing page where there is a horizontal panel consisting of the following tabs: "Navigation tab", "People", "Services", "Expertise", "Insights", and "Contact". I hovered over "Services", but the dropdown menu did not hint at a lead to the firm's price information. I then hovered over the navigation tab, and the drop-down menu provided an option - "Our Firm" - this option allowed me to read more about the firm. I clicked into this and was redirected to a different page. After scrolling through about three paragraphs of text, there was a hyperlink with the title "Client Charter". I clicked into the link and was redirected, again. It is on the "Client Charter" page where the information on how fees are charged was present; in the fifth paragraph of the page.

There were instances where the navigation through multiple links did not lead to the discovery of price information, and I had to use the website search bar. These firms form the third level of complexity ( 16.3 per cent, $n=8$ ), where price information could only be found via the search bar. In these instances, I entered "price" as a keyword into the search bar. If this did not generate any meaningful results on price information, I used the keywords "fees" or "rate" before finally searching the term "Terms of Engagement" in the search bar. Using search terms such as these requires a high level of knowledge about the legal services industry. However, this was the only way to find pricing information in eight of the 49 websites (16.3 per cent).

Having found the information, the next issue to explore was how easy the pricing information was to understand. The average readability score for law firms' websites that provided price information 
was equivalent to a 17 to 18 year old reading skill. Category A's websites provided their hourly rate, a slightly lower average readability score, comparable to a 15 to 16 year old. This is probably because the Flesch-Kincaid test emphasises the length of a sentence over each word's length within the sentence. Stating hourly rates (Category A) can be achieved in shorter sentences than explaining charging models (Category B).

\section{B Disclosure on Disbursements and Other Fees}

Besides reviewing pricing information for legal services, I also explored information about any other additional charges and fees. Of the 49 websites that provided price information, almost twothirds of them (61.2 per cent, $n=30)$ provided information on their billing practices. Such information included when invoices are sent to consumers and the period in which consumers are expected to make payments. This example is typical: ${ }^{65}$

We (the firm) will send interim invoices to you, usually monthly and on the completion of the matter or termination of our engagement. We may also send you an invoice when we incur a significant expense ... Invoices are payable within 14 days of the date of the invoice unless alternative arrangements have been made with us.

One in three websites that provided price information also provided information on how disbursements and other fees are charged (36.7 per cent, $n=18$ ). While some websites simply stated they charged disbursements, others explained in detail why a consumer would incur a disbursement fee: ${ }^{66}$

In providing services, we may incur disbursements or have to make payments to third parties on your behalf. These may include expenses such as Court filing fees, barrister fees, expert fees, travel expenses, couriers and fees of agents who serve documents or conduct investigations, searches and registration. These may also include any secretarial and/or word processing undertaken outside usual business hours. These disbursements and expenses will be included in our invoice to you when the expense is incurred. We may require an advance payment for the disbursements or expenses which we will be incurring on your behalf. We may also require that you enter a payment arrangement directly with the third party providing the relevant services ... We may charge you a general fee for our office services such as photocopying, faxing, and phone calls.

Where firms' websites outlined their disbursements policy, they sometimes stated a different rate for their "office charge", "service fee", or "bureau fee". These additional charges were typically for "office equipment rental, copying/printing, telephone/tolls/faxes, postage, stationery and library

65 Website 18.

66 Website 39. 
resources". ${ }^{67}$ These fees varied, often stating a dollar amount and/or a percentage, for example, "minimum of NZD 40.00 or $6 \% " .68$ The fees are calculated as a percentage ranging from 2.25 per cent to 7.00 per cent of the total billable amount. For those that quoted a fixed fee, the fees ranged from $\$ 16$ to $\$ 60$. There were, however, websites that informed consumers about such fees but did not state the specific rate or amount.

Over 40 per cent of the websites that provided price information notified consumers about the application of fees and interest rates regarding late payments ( 42.9 per cent, $n=21$ ). There was a wide variety of late payment charges across the different websites, and these charges became payable between seven days and two months after the receipt of the invoice. The applicable late fees were not always straightforward to calculate. The fees vary in how frequently they are compounded - daily, monthly, or annually - ranging from 1.5 per cent calculated monthly to 12 per cent calculated daily.

Some firms relied on their bank's carded rate before adding a margin to the applicable rates. For example, Website 19 stated that a four per cent per annum margin was added to their bank's base lending rate. In addition, website 19 outlined that fees were calculated daily, and clients were charged monthly - this form of information required high levels of literacy and numeracy for accurate interpretation.

\section{RESULTS OF EMPLOYMENT ADVOCATE WEB-SWEEP - SIMILARITIES AND DIFFERENCES}

I categorised the employment advocate websites using the same categories (A, B, C) for law firm websites. Twenty per cent $(n=6)$ were Category A, as they provided the employment advocates' hourly rates. Half of the websites fell into Category B (50.0 per cent, $n=15)$, as the websites described the pricing model or other fee calculation method but without stating the fees. The remainder (30.0 per cent, $\mathrm{n}=9$ ) were Category $\mathrm{C}$, providing no pricing information. These results show that employment advocates provide more pricing information than lawyers, although a significant proportion, like lawyers, provide no pricing information at all.

A close analysis of the information provided showed the differences in the type of information in Category B, both among employment advocates and in comparison to lawyers. The significant difference was the number of employment advocates offering no-win, no-fee (a normally prohibited arrangement for lawyers), although this was not consistent among advocates. Of the 15 employment advocates in Category B, four did not offer "no win, no fee" but briefly describe their price models. A further two websites provided a comprehensive explanation of how a "no win no fee" or contingency price model operates. For example, one of these two (Employment Advocate Website 9) outlined that for cases resolved before attending mediation under a contingency price model, the

67 Website 16.

68 Website 31. 
consumer "will be charged 25\%" plus the Goods and Services tax upon any financial settlement "up to the first $\$ 20,000$ " of the settlement and "nothing thereafter". The website further stated that the fee structure under the contingency price model changes for cases involving mediation and the Employment Relations Authority. Most websites (60.0 per cent, $n=9$ ) briefly mentioned a "no win, no fee" price model with no detail on how the fee would be calculated.

The websites that offered a "no win, no fee" arrangement but did not explain how it operated typically prompted consumers to make direct contact with the employment advocate by offering a free initial consultation. The offer of a "free initial consultation" to prospective consumers was commonly made on employment advocate websites (23.3 per cent $n=7$ (out of 30)). Notably, it was an offer absent from all 97 of the law firms' websites reviewed.

The average Flesch-Kincaid readability grade score for employment advocates' websites that offered price information ( 70.0 per cent, $n=21$ ) was equivalent to 14 to 15 years old. This average score is lower than that of the score derived from the law firms' websites. For employment advocates who provided their hourly rates on their websites (ie, Category A), the average readability grade score was also at a level suitable for 14-15 years old. For Category B employment advocate websites, the average score differed depending on the level of price information communicated. For employment advocate websites that described price structures other than a "no win, no fee" model, the readability grade score was equivalent to a 14 to 15 -year-old. Employment advocate websites explaining how a "no win, no fee" model operates, the readability level was equivalent to 17 to 18 years old. The websites that mentioned a "no win no fee" contingency fee arrangement but did not explain how what this meant; have a readability grade level of 10 to 11 years old.

Among the 21 employment advocates' websites that provided price information, only five of those websites ( 21 per cent, $n=4$ ) provided information on disbursement fees. Unlike the level of details on disbursement fees provided by law firms' websites, employment advocates' communication of disbursement fees was vague.

\section{DISCUSSION}

Robust market competition requires providers to deliver meaningful price information and for consumers to comprehend and utilise the given information. This article has suggested that consumers are likely to face difficulty navigating useful price information in the New Zealand legal services market. The web-sweep demonstrated that attaining price information was challenging and timeconsuming. Price information was often buried in law firms' terms of engagement, and searching such information demanded a higher readability level than those published directly on the firms' websites.

Drawing on the data derived from the web-sweep, the paper identified two phenomena relating to price transparency that are problematic for competition within the legal services market, especially those needing legal help in civil disputes. First, the search is costly for consumers. Because there is such limited price information available on law firms' websites, consumers are required to engage in more time-intensive searches such as visiting a law firm in person or making a phone call. This does 
not encourage comparison shopping. Secondly, even when consumers bear the search costs, the price information gathered is not always helpful in evaluating or comparing legal services. This is primarily due to the credence characteristics of legal services and the use of time-based billing. Therefore, the latter phenomenon can create a market condition where service providers have a relatively weak incentive to act competitively in terms of their pricing. ${ }^{69}$ Such a condition means that hourly rates are one of the few sources of information that a consumer may compare directly. However, the helpfulness of this information is limited.

While prospective clients facing employment-related disputes, who perceive price as a barrier, may be inclined to opt for an employment advocate due to the "no win, no fee" model, the invitation for a free consultation does not specify price information. This is due to the credence characteristics of employment dispute resolution. As a result, the use of an employment advocate does not necessarily reduce consumers' search costs. Additionally, it is essential to note in New Zealand, lawyers cannot charge a percentage of the recovery, ${ }^{70}$ and thus, such price information was not to be found on law firms' websites during the web-sweep.

Aligning with the Employment Law Institute of New Zealand, this article agrees that there is a need for statutory regulation of New Zealand employment advocacy services. ${ }^{71}$ Lawyers are bound by their Conduct and Client Care Rules and are subject to a complaints and disciplinary mechanism. As such, Lawyers' rules require fees to be fair and reasonable, factoring in, among other things, the time and labour expended, the skill needed for and the complexity of the matter, and the lawyer's ability. ${ }^{72}$ However, employment advocates are answerable only to general consumer law like the Consumer Guarantees Act. ${ }^{73}$ The employment advocates' regulation guidelines should clarify how price information should be advertised, such as the definition of a reasonable fee, particularly when there is a contingency fee arrangement and a standardised explanation to consumers on how the contingency fee arrangement operates.

This study recommends that regulators provide guides on the readability standard or a framework for quality price information. More commentaries from competition authorities are required around the late fees charged by lawyers. Sceptics of lawyers' self-regulation have called for competition authorities to take the lead and actively pursue policies designed to foster a competitive legal services industry, ${ }^{74}$ and this extends to both law societies and the body of employment advocates. Canada's

69 Semple, above n 34, at 200.

70 LCA, s 333(d).

71 The Employment Law Institute of New Zealand, above n 20.

72 Lawyers Rules, r 9.1 (a), (b), (f) and (g).

73 Consumer Guarantees Act 1993, pt 4.

74 Semple, above n 34, at 201. 
Competition Bureau, for example, has publicly declared that it seeks to "empower" consumers of legal services by providing them with the "access to accurate information" on price and that consumers can "benefit from a wide range of products and services at competitive prices". ${ }^{75}$

\section{CONCLUSIONS}

This web-sweep made it clear that New Zealand legal services providers do not behave in a manner that promotes price information availability and, therefore, a competitive market. Legal services possess credence qualities that do not allow consumers to compare the quality of the service easily. Consumers wanting to explore more on the quality of the legal service may rely on the law firms' reputation or through word-of-mouth review. However, there are limitations to this due to the varying nature of the legal services required. Findings from the web-sweep outline the difficulty of attaining price information such as lawyers' hourly rates and application of these rates. The difficulty of accessing such price information, therefore, is a barrier to access to justice. Current literature has argued that high search costs mean that consumers may be reluctant to embark on the task of finding and comparing prices across the industry. ${ }^{76}$ When there are barriers for consumers to compare providers' price offerings before making purchasing decisions, service providers may lose the economic incentive to compete by improving the price of those offerings. ${ }^{77}$ Therefore, a high search cost fails to lower the cost of litigation and the cost of representation, both of which are important to consumers' access to justice. ${ }^{78}$

Furthermore, this study revealed a scarcity of price information in the New Zealand non-lawyer dispute resolution services market. Consonant with the UK's Competition and Markets Authority's analysis, more is needed from regulators to change the current state of how service providers within the market communicate price information. ${ }^{79}$ A direct strategy that could alleviate the scarcity of price information is to require providers (law firms and employment advocates) to disclose price information on their websites. ${ }^{80}$ Providers should publish information on their price models, the applicable rates and fees on their websites. This would require an amendment to the regulation of lawyers. The New Zealand Law Society has expressed interest in regulation that might lower the price

75 Competition Bureau (Canada) 2015-2018 Strategic Vision (Competition Bureau Information Centre, 2015) <www.competitionbureau.gc.ca>. See also Competition Bureau (Canada) 2020-2024 Strategic Vision (Competition Bureau Information Centre, 2015) <www.competitionbureau.gc.ca>.

76 Ministry of Business, Innovation and Employment, above n 7, at 7. See also, Semple, above n 34, at 182.

77 United Nations Trade and Development Board Consumer protection and competition Policy: Note by the UNCTAD secretariat (United Nations Conference on Trade and Development, 2012) at 8.

78 Dippie, above n 11, at 25.

79 Competition and Markets Authority, above n 6, at 18.

80 This strategy may apply to advocates in other sectors, but that was beyond the scope of the current study. 
of legal services, and amendments to price information requirements could be part of this project. ${ }^{81}$ Regulation is also needed for the employment advocacy market. Simplifying costs and how service providers communicate these costs as price information to consumers will help remove a level of complexity for consumers comparing service providers. ${ }^{82}$ Regulating both groups would safeguard consumers' welfare and support access to legal services.

81 New Zealand Law Society Access to Justice: Stocktake of initiatives (New Zealand Law Society, December 2020) at [7.2]-[7.8].

82 Richard Moorhead "Filthy Lucre: Lawyers' Fees and Lawyers' Ethics - What is Wrong with Informed Consent" (2011) 31 LEGAL Stud 345 at 370 
(2021) 52 VUWLR 